九州大学学術情報リポジトリ

Kyushu University Institutional Repository

\title{
Comparative Study of the Collagen Content and Architecture of the Longissimus Muscle in Concentrate- and Forage - fed Male Goats
}

Shiba, Nobuya

Graduate School of Bioresource and Bioenvironmental Sciences, Kyushu University

Nakamura, Yoshi-Nori

Graduate School of Bioresource and Bioenvironmental Sciences, Kyushu University

Matsuzaki, Masatoshi

Laboratory of Animal Physiology and Meat Science, National Agricultural Research Center for Kyushu Okinawa Region

Tabata, Shoj i

Faculty of Agriculture, Kyushu University

他

https://doi.org/10.5109/4718

出版情報：九州大学大学院農学研究院紀要. 51 (1)，pp. 105-109，2006-02-01. Faculty of Agriculture, Kyushu University

バージョン :

権利関係 : 


\title{
Comparative Study of the Collagen Content and Architecture of the Longissimus Muscle in Concentrate- and Forage-fed Male Goats
}

\author{
Nobuya SHIBA ${ }^{1,2}$, Yoshi-Nori NAKAMURA ${ }^{1}$, Masatoshi MATSUZAKI ${ }^{3}$, \\ Shoji TABATA, Shotaro NISHIMURA, Eisaku TSUNEISHI ${ }^{3}$ \\ and Hisao IWAMOTO*
}

Laboratory of Functional Anatomy, Division of Animal Science, Department of Animal and Marine Bioresource Sciences, Faculty of Agriculture, Kyushu University, Fukuoka 812-8581, Japan

(Received October 5, 2005 and accepted November 16, 2005)

\begin{abstract}
Collagen content and architecture of the longissimus thoracis (LT) muscle were compared between the concentrate- and forage-fed male goats. During the experimental period of 9 to 26 wks old, the former gained $15.7 \mathrm{~kg}$ in body weight by feeding on commercial concentrate food and Italian ryegrass hay, while the latter gained only $2.4 \mathrm{~kg}$ by feeding on hay only. Dry matter, crude protein and crude fat were contained at significantly higher percentages in the LT muscle of the concentrate-fed goats than the forage-fed goats, and conversely, collagen content was significantly higher in the muscle of the latter. However, the collagen pyridinoline content did not differ between them. The myofibers in the concentrate-fed goats $(54.0 \mu \mathrm{m})$ were twice the size of those in the forage-fed goats $(25.5 \mu \mathrm{m})$. The higher content of crude fat $(2.89 \%)$ in the LT muscle of the concentrate-fed goats was not enough for adipose tissues to develop within the perimysium as marbling. Immunohistochemical methods revealed types I and III collagens over both perimysium and endomysium. Thin collagen bundles were loosely distributed in the perimysium of concentrate-fed goats muscles, and conversely, the perimysial architecture in the forage-fed goats muscles appeared as dense stacks of thick collagen fibers. From these results, it was indicated that the development of loose tissues of slender collagen fibers had an intimate relationship with the rapid growth rate of muscle rather than the development of adipose tissue.
\end{abstract}

\section{INTRODUCTION}

When intramuscular proteins are divided into myofibrillar (salt-soluble), connective tissue (acid-soluble) and sarcoplasmic (water-soluble) fractions, the connective tissue fraction occupies only $15 \%$ of the overall protein (Helander, 1966; Koohmaraie et al., 2002). The connective tissue proteins are contained as collagen, elastin, proteoglycans and structural proteins (fibronectin, laminin and so on) (Fawcett, 1994). Although the total amount of collagen is only $2-6 \%$ of total dry weight of most muscles (McCormick, 1994), plenty collagen fibrils or fibres such as types I and III develop within thicker perimysium (Listrat et al., 1999; Nakamura et al., 2003) and have a harmful effect on meat tenderness (Purslow, 1999).

Collagen fibrils and fibers appear in different architectures between perimysium and endomysium, the perimysium is made up mainly of thick bundles of collagen fibrils (fibers), but the endomysium shows a fine reticular network of collagen fibrils with a small number of thin bundles (Iwamoto et al., 2001). Adipose tissue

1 Laboratory of Functional Anatomy, Division of Animal Science, Department of Animal and Marine Bioresource Sciences, Graduate School of Bioresource and Bioenvironmental Sciences, Kyushu University

${ }^{2}$ Present address: Meat Quality Control Laboratory, National Agricultural Research Center for Tohoku Region, Morioka-shi 020-0198, Japan

${ }^{3}$ Laboratory of Animal Physiology and Meat Science, National Agricultural Research Center for Kyushu Okinawa Region, Nishigoshi-machi, Kumamoto-ken 861-1192

* Corresponding author (E-mail: hiwamoto@agr.kyushu-u.ac.jp) develops within the perimysium, especially in wide portions surrounded by corners of three or more myofiber bundles (Nishimura et al., 1999; Nakamura et al., 2003). Nishimura et al. (1999) reported that the development of the adipose tissue effectively contributes towards the tenderization of meat by breaking away the collagen fibers in the perimysium of the longissimus muscle of fattened cattle. As every adipose cell is protected by a fine reticular network of collagen fibrils, similar to the endomysial network (Nakamura et al., 2003), the development of thick perimysial collagen fibers seems to play a main role in the enhancement of meat toughness.

To improve the mechanical and thermal stability of collagen fibrils, cross-links establish within collagen with muscle growth and exert a harmful effect on meat tenderness (Bailey, 1984). Because of the lower demand for tensile strength of collagen in the muscles of sheep and goat due to their smaller body size, pyridinoline content tends to be lower compared to in cattle and pigs (Horgan et al., 1991; McCormick, 1994). While collagen solubility decreases with growth (Cross et al., 1973, 1984; Hill, 1966; Reagon et al., 1976), pyridinoline cross-linking becomes contained in collagen at a higher frequency (Steinhart et al., 1994).

This study compares the collagen content and architecture of the longissimus muscle in concentrate- and forage-fed 9 to 26 -week-old male goats.

\section{MATERIALS AND METHODS}

\section{Materials}

Male Japanese Saanen kids were weaned at 4 wks and reared in pens with free access to a concentrate diet 
(TDN 70\%, CP 15\%) and Italian ryegrass hay until 9 wks. A concentrate-fed group consisting of 5 goats was then continued on the same diet and a forage-fed group consisting of 4 goats was changed to a diet of hay only. At 26 wks the goats were killed under deep anesthesia by intravenous injection of sodium pentobarbitone and the longissimus thoracis (LT) muscle was excised. Two blocks about $1 \mathrm{~cm}^{3}$ containing parallel myofiber striations were dissected from the center of the LT muscle at the $12^{\text {th }}$ thoracic vertebra. One block was then rapidly frozen in a dry ice-acetone mixture for histological observation and the other was fixed in $2 \%$ glutaraldehyde plus $2 \%$ paraformaldehyde in a $0.02 \mathrm{M}$ phosphate buffer solution (pH 7.4, PBS) for several days at $4^{\circ} \mathrm{C}$ for scanning electron microscopic observation. The remaining materials (more than $100 \mathrm{~g}$ ) were frozen with dry ice for measurements of chemical composition such as dry matter, crude fat, crude protein, collagen, and pyridinoline in each group.

\section{Immunohistochemical methods}

After a pretreatment with normal goat serum $(10 \mathrm{~mL} / \mathrm{L})$ (Sigma-Aldrich, St louis, USA) in PBS, non-fixed frozen sections ( $8 \mu \mathrm{m}$ thick) were stained for types I and III collagens (Hsu et al., 1981). In these methods, rabbit anti-bovine collagen type I polyclonal antibody and collagen type III antibody (LSL Co. Ltd, Nagahama, Japan, Lot No 862120 and 862112), both diluted 1:500 with PBS, were used as primary antibodies, with biotinylated goat antirabbit IgG as secondary, followed by avidin-biotin conjugate $(\mathrm{ABC})$ reagents (Vector Laboratories, Burlingame, USA). Combined peroxidase was developed with a substrate consisting of $0.1 \%$ diaminobenzidine tetrahydrochloride. Using the type I collagen preparations, the diameters of 200 myofibers in each animal were measured as the maximum dimension perpendicular to its long axis.

\section{Collagen content}

A sample solution was prepared according to the method of Hill (1966). After isopropanol, an oxidant solution ( 1 volume of $7.5 \% \mathrm{w} / \mathrm{v}$ chloramines $\mathrm{T}$ and $3 \mathrm{vol}-$ umes of acetate/citrate buffer ( $\mathrm{pH} \mathrm{6.0))} \mathrm{and} \mathrm{Ehrlich's}$ reagent were added to each sample, the sample was then incubated at $60^{\circ} \mathrm{C}$ for $25( \pm 15) \mathrm{min}$ and cooled to $20^{\circ} \mathrm{C}$ followed by dilution with isopropanol. Within $4 \mathrm{~h}$ of the sample's preparation, spectrophotometric determination of hydroxyplorine at $560 \mathrm{~nm}$ was carried out (Bergman and Loxley, 1963). As skeletal muscle collagen contains $13.3 \%$ hydroxyproline, the total collagen content was calculated by multiplying the hydroxyproline content by 7.25 (Goll et al., 1963; Cross et al., 1973).

\section{Determination of pyridinoline content}

Pyridinoline was purified according to the method of Skinner (1982), and pyridinoline content was determined by the HPLC procedure developed by Arakawa $e t$ al. (1992). Cellulose slurry was prepared by mixing $10 \mathrm{~g}$ of $\mathrm{CF}_{1}$ cellulose (Whatman $\mathrm{CF} 1$, Kent, UK) with $200 \mathrm{ml}$ of the mobile phase $n$-butanol-acetic acid-water (4:1:1). Columns ( $7 \mathrm{~mm}$ I.D.) made from Sterilin disposable plastic pipettes (No. 40305; Bibby Sterilin Ltd., Staffordshire, UK) by plugging the tip with a piece of cotton wool, were packed with $4-5 \mathrm{ml}$ of the slurry to a height of $45-50 \mathrm{~mm}$ followed by washing with $5 \mathrm{ml}$ of mobile phase.

The hydrolysed solution samples $(8 \mathrm{ml})$ for determination of collagen content were concentrated into $0.75-1.00 \mathrm{ml}$ and the concentrated samples were then mixed with, in the following order, acetic acid $(0.5 \mathrm{ml})$, cellulose slurry $(0.5 \mathrm{ml})$ and n-butanol $(2 \mathrm{ml})$. The mixed slurry samples were transferred onto a prepared column followed by washing with $15 \mathrm{ml}$ of mobile phase to remove hydrochloric acid and amino acids. The pyridinoline-containing fraction was eluted from the column into a test tube with $5 \mathrm{ml}$ of water and dried by evaporation at low pressure with a concentrator. For the HPLC analysis, the dried residue of fraction was dissolved in $0.5 \mathrm{ml}$ of water and filtered through a $0.45-\mu \mathrm{m}$-mesh filter.

Using a Hitachi (Tokyo, Japan) L-7000 HPLC system equipped with Hitachi L-7480 spectrofluorophotometer and stainless steel column (Shimadzu Shim-pack CLC-ODS (M); $\mathrm{C}_{18}, 5 \mu \mathrm{m}, 25 \mathrm{~cm} \times 4.6 \mathrm{~mm}$, Shimadzu, Kyoto, Japan), $20 \mu$ l of each sample was analysed for determination of pyridinoline content. A mixture of $0.1 \mathrm{M}$ sodium phosphate and acetonitrile $(75: 25, \mathrm{v} / \mathrm{v})$ containing SDS ( $\mathrm{g} / \mathrm{l})$ and EDTA $(25 \mathrm{mg} / \mathrm{l})$ was used as the mobile phase at a flow rate of $1 \mathrm{ml} / \mathrm{min}$. Pyridinoline concentration was measured by fluorescence intensity at $395 \mathrm{~nm}$ with excitation at $295 \mathrm{~nm}$ compared with the intensity of an external standard purchased from Wako (Oosaka, Japan).

\section{Scanning electron microscopic observation}

The fixed materials were sliced transversely with a razor and macerated in $2 \mathrm{~N} \mathrm{NaOH}$ solution for 5 days using a slightly modified method of Tabata et al. (1995). The macerated specimens were rinsed in distilled water for 2 days at $25^{\circ} \mathrm{C}$, treated with $1 \%$ tannic acid for $2 \mathrm{~h}$, and postfixed with $1 \%$ osmium tetraoxide solution for $2 \mathrm{~h}$. After dehydration in a graded series of ethanol, the specimens were placed in t-butyl alcohol and freeze-dried (TIS-U-DRY, FIS Systems, New York, USA). The specimens were then mounted on aluminium holders and coated with Pt-Pd (Eiko IB3, Hitachinaka, Japan). The collagen architecture of the muscles was examined under a scanning electron microscope (SEM, Super Scan SS-550, Shimadzu, Kyoto, Japan) at an accelerating voltage of $15 \mathrm{kV}$.

\section{Statistical analysis}

The means and standard errors were calculated and used for examination of significant differences between the treatment groups using the student's $t$-test for body weight, chemical composition, and myofiber diameter.

This experiment was carried out under the control of the guideline for Animal Experiment in Faculty of Agriculture and the Graduate Course, Kyushu University 
and the Law (No. 105) and Notification (No. 6) of the Government.

\section{RESULTS}

Body weights, chemical compositions, and myofiber size

Different growth rates were observed between the concentrate- and forage-fed goats. The former gained $15.7 \mathrm{~kg}$ in body weight from $10.5 \mathrm{~kg}$ at $9 \mathrm{wks}$ to $26.2 \mathrm{~kg}$ at $26 \mathrm{wks}$, while the latter gained only $2.4 \mathrm{~kg}$ from $10.8 \mathrm{~kg}$ to $13.2 \mathrm{~kg}$, respectively, throughout the experiment period (Table 1).

Dry matter, crude fat and crude protein were measured at significantly higher percentages in the concentrate-fed goats than the forage-fed goats at a $1 \%$ significance level (Table 1). The marked difference in dry matter ( $4.2 \%)$ between the two groups was attributed to differences in crude fat content (2.57\%) and crude protein content $(1.9 \%)$. Conversely, in the forage-fed goats, the total amount of collagen occupied a significantly larger part of the crude protein $(\mathrm{P}<0.01)$. However, the pyridinoline content of the collagen did not differ between the animal groups.

The muscle of the concentrate-fed goats was composed of myofibers of larger mean size indicating the high growth rate of the LT muscle (Table 1).

\section{Collagen fiber structures}

Type I collagen was detected immunohistochemically as wide perimysial bands and nets of endomysial thread (Fig. 1a, b) and also type III was distributed in the perimysium and the endomysium. When the forage-fed and concentrate-fed goats were compared, the perimysial bands were thicker in width and closer in mesh in the former. The mesh of endomysial net was also closer in the forage-fed goats than the concentrate-fed.

In the forage-fed goats, low magnification SEM micrographs of the LT muscle (Fig. 2a) exhibited well-developed perimysial collagen ridges projecting from a plane of endomysial honeycomb structures, because of their different shrinkage rates during preparation. On the other hand, in the concentrate-fed goats, perimysial collagen bands were observed along the same plane as the endomysial honeycomb structures (Fig. $2 b$ ). The well-developed perimysium of the forage-fed goats was filled up with stacks of thick collagen fibers showing longitudinal, oblique and transverse striations (Fig. 3a). The perimysium of the concentrate-fed goats consisted of loose tissues of thin collagen bundles and fine fibrils showing mainly transverse striation (Fig. 3b).

In the high magnification SEM micrograph of the forage-fed goats, thick collagen fibers contacted intimately with each other and formed a plate of thick fibers crossed over with thin collagen bundles or fibrils (Fig. 4a). Each collagen fiber was composed of a net-like

Table 1. Live weight, chemical composition, and myofiber diameter of longissimus thoracis muscle in the forage- and concentrate-fed goats.

\begin{tabular}{lccc}
\hline Male goats & $\begin{array}{c}\text { Forage-fed } \\
\text { No. of animals }\end{array}$ & $\begin{array}{c}\text { Concentrate-fed } \\
5\end{array}$ & Significant level \\
\hline Body weights & & & \\
$\quad$ Initial weight (9 wks old) & $10.8 \pm 0.7$ & $10.5 \pm 0.6$ & $\mathrm{NS}$ \\
$\quad$ Final weight $(26$ wks old) & $13.2 \pm 0.5$ & $26.2 \pm 1.1$ & 0.01 \\
Chemical composition & & & \\
$\quad$ Dry matter & & $25.6 \pm 0.2$ & 0.01 \\
Crude Fat $^{1}$ & $0.32 \pm 0.4$ & $2.89 \pm 0.28$ & 0.01 \\
Crude protein $^{1}$ & $19.5 \pm 0.3$ & $21.4 \pm 0.3$ & 0.01 \\
Collagen content $^{2}$ & $2.76 \pm 0.42$ & $1.16 \pm 0.03$ & 0.01 \\
$\quad$ Pyridinoline content $^{3}$ & $0.21 \pm 0.02$ & $0.22 \pm 0.01$ & $\mathrm{NS}$ \\
Myofiber diameter $(\mu \mathrm{m})$ & $25.5 \pm 0.1$ & $54.0 \pm 0.1$ & 0.01 \\
\hline
\end{tabular}

Means \pm Standard errors. NS; not significant at $5 \%$ level.

${ }^{1} \%$ of wet material.

${ }^{2} \%$ of crude protein.

${ }^{3} \mathrm{~mol}$ of mol collagen.
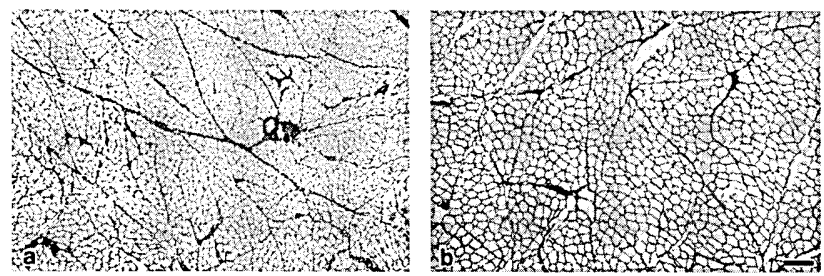

Fig. 1. Type I collagen stained by immunohistochemical methods in the longissimus muscle of the forage- (a) and concentrate-fed (b) goats. Bar $=200 \mu \mathrm{m}$.

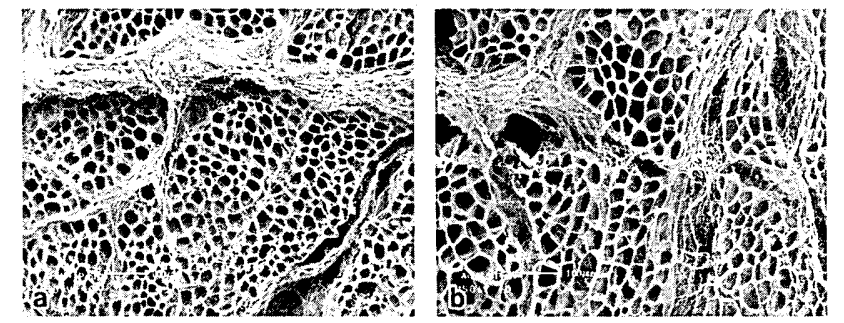

Fig. 2. Low magnification SEM photographs in the longissimus muscle of the forage- (a) and concentrate-fed (b) goats. 

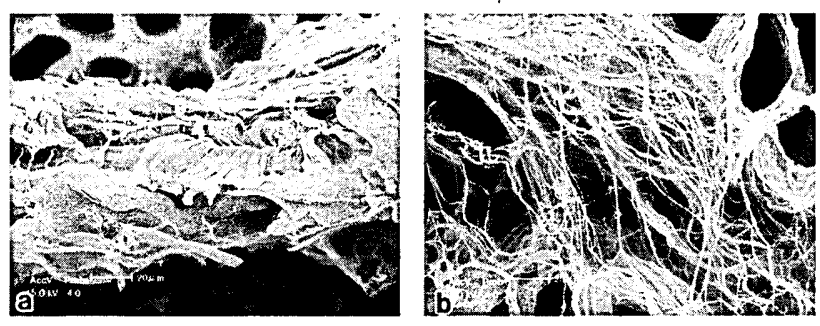

Fig. 3. Middle magnification SEM photographs of perimysia in the longissimus muscle of the forage- (a) and concentrate-fed (b) goats.
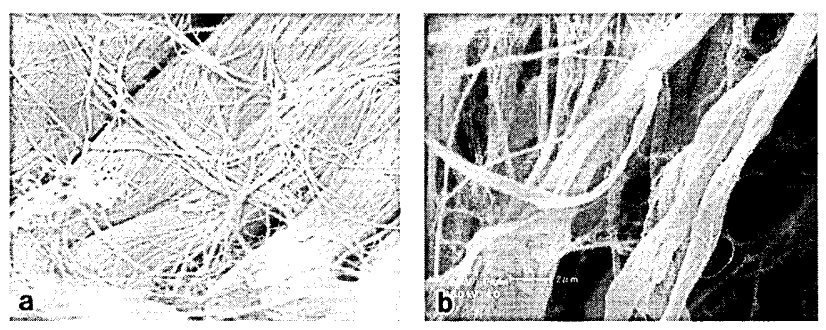

Fig. 4. High magnification SEM photographs of perimysia in the longissimus muscle of the forage- (a) and concentrate-fed (b) goats.
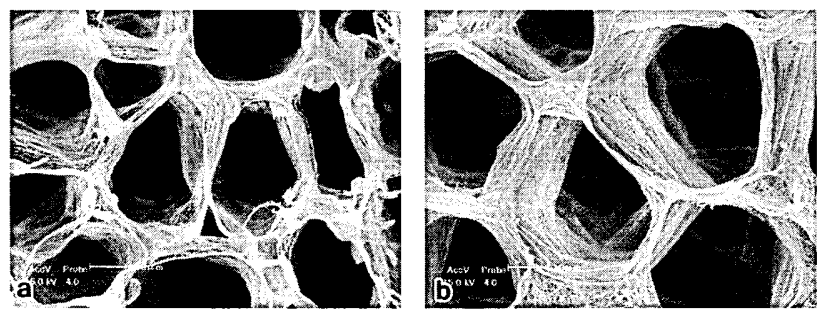

Fig. 5. Middle magnification SEM photographs of endomysia in the longissimus muscle of the forage- (a) and concentrate-fed (b) goats.

structure of bundles with a slim mesh of repeated divergence and agglutination of collagen bundles or fibrils. In the concentrate-fed goats, the perimysial collagen was scarcely distributed as slender collagen bundles with some connecting twigs (Fig. 4b).

In both groups, the endomysial honeycomb structure was composed of numerous different sized cells with no myofibers (Fig. 5a, b). However, the cell walls of the meshwork of collagen fibrils or thin bundles showed similar thickness.

\section{DISCUSSION}

Nutritional improvements as a result of a concentrate diet enhanced body growth and development of the LT muscle in male goats with regards to chemical composition, that is, dry matter, crude protein and crude fat levels. However, the high content of crude fat in the LT muscle of the concentrate-fed goats was not enough for fat to be deposited within the perimysium like the adipose tissue observed electron microscopically by Nishimura et al. (1999) and Nakamura et al. (2003). Although it has been reported that adipose tissue con- tributes to meat tenderisation by breaking away thick collagen fibers from the perimysium (Nishimura et al., 1999), the present SEM micrographs of the concentrate-fed goats showed loose tissues of thin collagen bundles within the perimysial portion containing no adipose tissue. The results of the present study indicated that the development of perimysial thick collagen fibers was arrested in the concentrate-fed goats with rapid growth. In the $\mathrm{LT}$ muscle of these goats, rapid accumulation of crude proteins should be based mainly in the myofibrillar and sarcoplasmic fractions (enlargement of the myofibers) and slightly in the connective tissue fraction for a relatively slow rate of collagen biosynthesis (Helander, 1966; Koohmarie et al., 2002).

In a slow-growing turkey line, the pectoralis muscle was tougher because it contained a higher percentage of collagen compared with a fast-growing line (Fernandez et al., 2001). In a selected duck line with greater body weight, the iliotibialis cranialis (sartorius) muscle contained a lower percentage of collagen than that in normal ducks (Baeza et al., 2002). These results are consistent with those of the present study, which showed a lower content of collagen in the LT muscle of concentrate-fed goats. The collagen content in the concentrate-fed goats was calculated as $2.48 \mathrm{mg} / \mathrm{g}$ of muscle tissue, which was about the same level as that in the tender LT muscle of pigs $(2.66 \mathrm{mg} / \mathrm{g}$ ) (Nakamura $e t$ $a l ., 2003)$. On the other hand, the collagen content in the LT muscle of forage-fed goats $(5.38 \mathrm{mg} / \mathrm{g}$ of muscle tissue) was more than that seen in the tougher pectoralis profundus muscle of the pigs $(4.13 \mathrm{mg} / \mathrm{g})$. A high correlation coefficient $(r=0.723, \mathrm{P}<0.01)$ was recognized between the total amounts of collagen and Warner- Bratzler shear force values of the muscles of young bulls (Torrescano et al., 2003).

During growth, pyridinoline becomes contained in collagen at a higher percentage (Steinhart et al., 1994) and collagen solubility decreases (Hill, 1966; Cross et al., 1973, 1984; Reagon et al., 1976). A drastic change in collagen solubility is observed during growth before 2 yr old in meat animals (Hill, 1966). Because the goats studied here were the same age ( $26 \mathrm{wks})$, the two groups did not show any difference in the amount of pyridinoline in the LT muscle regardless of the different total amounts of collagen and different structures of the perimysial collagen fibers. From these results, since development of pyridinoline cross-linking is affected solely by age rather than collagen content and structure, meat toughness might have an intimate relationship with the total amount of collagen in animals of the same age (Torrescano et al., 2003).

In conclusion, nutritional improvements as a result of a concentrate diet enhanced LT muscle growth through rapid accumulation of protein for myofiber growth and a relatively slower deposition of proteins, especially collagen, around myofibers. Because of the different rates of protein accumulation within and outside the myofibers, the loose tissues of slender collagen fibers developed in the perimysia of the concentrate-fed goats muscle, which contained no adipose tissue. 


\section{ACKNOWLEDGEMENTS}

We express many thanks to the staff of the Center of Advanced Instrumental Analysis, Kyushu University, for their advice and help with the Scanning Electron Microscope.

\section{REFERENCES}

Arakawa, N., M. Kim and M. Otsuka 1992 An improved high-performance liquid chromatographic assay for the determination of pyridinoline in connective tissues. Journal of Nutritional Science and Vitaminology, 38: 375-380

Baeza, E., C. Dessay, N. Wacrenier, G. Marche and A. Listrat 2002 Effect of selection for improved body weight and composition on muscle and meat characteristics in Muscovy duck. British Poultry Science, 43: 560-568

Bailey, A. J. 1984 The Chemistry of intramolecular collagen. In "Recent Advances in the Chemistry of Meat", ed. by A. J. Bailey, The Royal Society of Chemistry, London. pp. 22-40

Bergman, I. and R. Loxley 1963 Two improved and simplified methods for the spectrophotometric determination of hydroxyproline. Analytical Chemistry, 35: 1961-1965

Cross, H. R., Z. L. Carpenter and G. C. Smith 1973 Effects of intramuscular collagen and elastin on bovine muscle tenderness. Journal of Food Science, 38: 998-1003

Cross, H. R., B. D. Schanbacher and J. D. Crouse 1984 Sex, age and breed changes in bovine testosterone and intramuscular collagen. Meat Science, 10: 187-195

Fawcett, D. W. 1994 A Textbook of Histology 12th edn. Chapman \& Hall, New York / London.

Fernandez, X., V. Sante, E. Baeza, E. Lebihan-Duval, C. Berri, H. Remignon, R. Babile, G. Le Pottier, N. Millet, P. Berge and T. Astruc 2001 Post mortem muscle metabolism and meat quality in three genetic types of turkey. British Poultry Science, 42: 462-469

Goll, D. E., W. G. Hoekstra and R. W. Bray 1963 Age-associated changes in muscle composition. The isolation and properties of a collagenous residue from bovine muscle. Journal of Food Science, 28: 503-509

Helander, E. 1966 General consideration of muscle development. In "The Physiology and Biochemistry of Muscle as a Food" ed. by E. J. Brisky, R. G. Cassens and J. C. Trautman, The University of Wisconsin Press, Madison/Milwaukee/London, pp. 19-29

Hill, F. 1966 The solubility of intramuscular collagen in meat animals of various ages. Journal of Food Science, 31: 161-166

Horgan, D. J., P. N. Jones, N. L. King, L. B. Kurth and R. Kuypers 1991 The relationship between animal age and the thermal stability and cross-link content of collagen from five goat muscles. Meat Science, 29: 251-262

Hsu, S. M., L. Raine and H. Fanger 1981 Use of avidine-biotine-peroxidase complex $(\mathrm{ABC})$ in immunoperoxidase techniques: a composition between $\mathrm{ABC}$ and unlabeled antibody (PAP) procedures. Journal of Histochemistry and Cytochemistry, 29: 577-580

Iwamoto, H., S. Tabata, K. Sakakibara, S. Nishimura, T. Gotoh and Y. Koga 2001 Scanning electron microscopic observation of the architecture of collagen fibres in chicken $M$. iliotibialis lateralis. British Poultry Science, 42: 321-326

Koohmarie, M., M. P. Kent, S. D. Shackelford, E. Veiseth and T. L. Wheeler 2002 Meat tenderness and muscle growth: is there any relationship? Meat Science, 62: 345-352

Listrat, A., B. Picard and Y. Geay 1999 Age-related changes and location of type I, III, IV, V and VI collagens during development of four foetal skeletal muscles of double-muscled and normal bovine animals. Tissue and Cell, 31: 17-27

McCormick, R. J. 1994 The flexibility of the collagen compartment of muscle. Meat Science, 36: 79-91

Nakamura, Y. -N., H. Iwamoto, Y. Ono, N. Shiba, S. Nishimura and S. Tabata 2003 Relationship among collagen amount, distribution and architecture in the $M$. longissimus thoracis and M. pectoralis profundus from pigs. Meat Science, 64: 43-50

Nishimura, T., A. Hattori and K. Takahashi 1999 Structural changes in intramuscular connective tissue during the fattening of Japanese Black cattle: effect of marbling on beef tenderisation. Joumal of Animal Science, 77: 93-104

Purslow, P. P. 1999 The intramuscular connective tissue matrix and cell/matrix interactions in relation to meat toughness. Proceedings 45th International Congress of Meat Science and Technology, 1-6 August 1999, Vol. I, Yokohama, Japan, pp. 210-219

Reagen, J. O., Z. L. Carpenter and G. C. Smith 1976 Age-related traits affecting the tenderness of the bovine longissimus muscle. Journal of Animal Science, 43: 1198-1205

Skinner, S. J. M. 1982 Rapid method for the purification of the elastin cross-links, desmosine and isodesmosine. Journal of Chromatgraphy, 299: 200-204

Steinhart, H., A. Bosselmann and C. Moller 1994 Determination of pyridinolines in bovine collagenous tissues. Journal of Agriculture and Food Chemistry, 42: 1943-1947

Tabata, S., T. Nakayama, K. Yasui and M. Uemura 1995 Collagen fibrils in the odontoblast layer in the teeth of the rat and the house shrew, Suncus murinus, by scanning electron microscopy using a maceration method. Connective Tissue Research, 33: 115-121

Torrescano, G., A. Sanchez-Escalante, B. Gimenez, P. Roncales and J. A. Beltran 2003 Shear values of raw samples of 14 bovine muscles and their relation to muscle collagen characteristics. Meat Science, 64: 85-91 